\title{
Recent Trends in U.S. Arctic Affairs ${ }^{1}$
}

\author{
LISLE A. ROSE ${ }^{2}$
}

There now exists in the United States a growing recognition that the country has new, important, and expanding interests in the Arctic that often equal the national security concerns that have existed since World War II.

A strong and active national presence in the Arctic first became necessary in 1940-41 when it appeared that Nazi air power seemed sufficient to strike the North American continent at least a glancing blow from Europe, utilizing arctic air space. U.S. arctic security interests and presence were further enhanced in the mid-1950s by the realization that developing missile and bomber technologies had dramatically shortened the assault time upon North America by potential aggressors from the Eurasian landmass. Construction of the Distant Early Warning (DEW) Line across arctic Alaska and portions of Canada, establishment of the North American Air Defence (NORAD) system, and the establishment of the Ballistic Missile Early Warning System (BMEWS) in Greenland, all between 1955 and 1960, marked the first important surge of major U.S. activity and presence in the Arctic.

A second surge took place between the late sixties and the mid-seventies with the discovery and eventual exploitation of substantial oil reserves at Prudhoe Bay on Alaska's North Slope and the subsequent construction of the Trans-Alaska Pipeline to Valdez. Prudhoe Bay raised for the first time the prospect that resources in U.S. arctic coastal zones and the adjacent submerged lands of the Outer Continental Shelf (OCS) could substantially contribute to national energy reserves and security. At the same time, the prospect of significant industrial activity in the U.S. Arctic generated deep concern among native peoples about the effects of technological and developmental changes and programs upon their lives, society, culture, and property. The eventual need to transport exploited arctic resources by sea to southern refineries and market areas raised among the circumpolar nations the issue of freedom of navigation versus national rights of pollution control in arctic waters and passageways. The issue was further dramatized in 1969-70, when the icecapable U.S. tanker Manhattan made an exploratory voyage through the Northwest Passage, which was claimed by Canada as internal waters.

The developments and concerns stimulated by the Prudhoe Bay program never fully subsided during the 1970 s because of the global energy production and pricing crisis that began in 1973-74, the demands of the Alaskan native peo- ples for equitable reimbursement for lands and resources surrendered to possible development, and the outstanding juridicial issues among the arctic states. By 1975, it was clear that future exploration and exploitation of Alaskan OCS resources were inevitable, in light of the need for secure national energy resources. Canada was proceeding vigorously with offshore development plans on its side of the Beaufort Sea boundary, possibly with substantial impact upon U.S. waters and coastal zones in the event of industrial accidents.

The increasing attention paid to arctic energy plans and programs after 1974 was matched by years of careful scientific research that revealed the importance of the Arctic in and to the entire global physical system. The arctic "heat budget" created by the interaction of ocean, sea ice, and atmosphere was discovered to determine the rate of change of hemispheric climate in important ways, even as the "budget" was shown to be vulnerable to disruption by pollutants carried into the region from distant industrial centers (Aagaard et al., 1979; Aagaard, in press; Rahn, in press). The north polar magnetic fields were discovered to play an important role in determining the stability of the entire planetary magnetic system. Satellite and groundbased observations over the past two decades indicate that the region surrounding the northern geomagnetic pole is directly connected to the interplanetary magnetic field, thus providing solar wind particles direct access to the high-latitude atmosphere. Interaction of solar winds with the magnetosphere in turn creates magnetic fields across the entire polar cap, which lead to convective motion of the entire polar atmosphere with strong effects down to middle latitudes (Stern, 1979; Sojka et al., 1982; Foster and Burrows, 1977).

It is now widely perceived in U.S. government, business, and academic circles, as well as in Alaska, that there will be a dramatic enlargement of human presence and activity in the U.S. Arctic during this decade. It is also well recognized that other arctic nations, most notably Canada and the Soviet Union, have already embarked on a formidable array of activities that in many instances substantially exceed those contemplated in the U.S. Arctic. As a result, there has emerged a spectrum of often interrelated economic, environmental, scientific, social, and legal issues that will have to be resolved both nationally and internationally. The government, the scientific community, and private developers have begun to confront such prob-

\footnotetext{
'The views set forth here are solely those of the author and do not necessarily reflect the views and policies of the Department of State or the United States Government.

${ }^{2}$ Polar Affairs Officer, Bureau of Oceans and International Environmental and Scientific Affairs, Department of State, Washington, D.C. 20520, U.S.A.
} 
lems as: outstanding international boundary issues; native populations' vocal apprehension about the social, environmental, and cultural impact of resource development and industrialization on the circumpolar area; the degree and kind of scientific, technological, and engineering research required to ensure cost-effective, environmentally safe exploration, production and transportation of resources; the nature and amount of government support services required by national law and treaty obligations to ensure safe operations by private developers; and many other related questions.

Program and policy evaluation is underway on many fronts. In 1979 the executive branch of the federal government revived and reconstituted the formerly dormant Interagency Arctic Policy Group (IAPG) under the chairmanship of the Assistant Secretary of State for Oceans, International Environmental and Scientific Affairs. The IAPG is currently considering a working-group report on future federal levels of effort in the Arctic in light of anticipated private resource development programs there. The National Petroleum Council (NPC), which is an advisory committee of private industry to the Department of Energy, has completed a comprehensive study of anticipated oil and gas development programs in the U.S. Arctic between now and the end of this century. The Polar Research Board (PRB) of the National Academy of Sciences has empaneled a group to study the feasibility of and necessity for a comprehensive and coherent U.S. arctic science policy and program. Additional study groups within the PRB are evaluating specific arctic research projects on terrestrial environment, permafrost, biomedicine, and upper atmospheric physics, among others. Finally, Congress has exhibited increasing interest in the question of arctic science programs and policies. Section 1007 of the Alaska National Interest Lands Conservation Act of 1980 mandated a study of U.S. arctic research policy and the possible roles of the Naval Arctic Research Laboratory at Barrow, Alaska. This study was to be submitted to Congress by the Secretary of the Interior no later than the end of 1981. On 31 July 1981, Senator Murkowski (Alaska), on behalf of Senators Stevens (Alaska) and Jackson (Washington), submitted to Congress a bill (S-1562) to provide comprehensive national policy dealing with national needs and objectives in the Arctic. The bill is formally entitled "Arctic Research and Policy Act of 1981". Among other measures, the proposed legislation would provide for establishment of an Arctic Research Council under the direction of the Secretary of the Interior.

This flurry of recent activity occurs against a background of steadily expanding U.S. research effort in the Arctic during the past decade, much of it in cooperation with foreign scientific teams and institutions. Programs have spanned a range of interest from sea-ice dynamics (AIDJEX) and physical oceanography (EUBEX) to terrestrial ecosystems (IBP) and oil spill assessment (AMOP) to social consequences of expanded human presence and activity ("Man in the Arctic"). The longest and most comprehensive effort has been the Outer Continental Shelf Environmental Assessment Program (OCSEAP) begun in 1975 by the Department of the Interior Bureau of Land Management and the National Oceanic and Atmospheric Administration. OCSEAP was initiated partly to provide the necessary baseline data for the Environmental Impact Statements required by law for proposed offshore oil and gas development activities.

The precise dimensions of U.S. arctic activities and policies during this decade and beyond remain to be determined. The pace of and incentives for resource development will have to be decided by private enterprise as it balances projected demand against program costs. The appropriate roles of federal, state, and local governments in resource development have not yet been precisely evaluated. The degree to which various programs will create pressures and opportunities for enhanced international cooperation remains unclear. What is certain is that the United States is on the verge of a permanently enlarged and multifaceted presence in the Arctic that will require careful policy evaluation and formulation in both the private and public sectors. Renewed national interest in the Arctic ensures that such policy evaluation and formulation will be forthcoming at an early date.

\section{REFERENCES}

AAGAARD, K. 1982 (in press). Inflow from the Atlantic to the Polar Basin. In: Reye, L. (ed.). Proceedings of the Conference. The Arctic Ocean: The Hydrographic Environment and the Fate of Pollutants. 11-12 March 1980, London, England.

CARMACK, E.C., FOLDVIK, A., KILLWORTH, P.D., LEWIS, E.L., MEINCKE, J. and PAULSEN, C.A. 1979. The Arctic Ocean Heat Budget. University of Bergen, Geophysical Institute Report No. 52.

FOSTER, J.C. and BURROWS, J.R. 1977. Electron fluxes over the polar cap. Journal of Geophysical Research 82 (November):5165ff.

RAHN, K. 1982 (in press). On the causes, characteristics and potential environmental effects of the aerosol in the arctic atmosphere. In: Reye, L. (ed.). Proceedings of the Conference. The Arctic Ocean: The Hydrographic Environment and the Fate of Pollutants. 11-12 March 1980, London, England.

SOJKA, J.J., SCHUNK, R.W. and RAITT, W.J. 1982. Seasonal variations of the high latitude $F$ region for strong convection. Journal of Geophysical Research 87(January): $187 f f$.

STERN, D.B. 1979. The electrical field and electrodynamics of the magnetosphere. Reviews of Geophysics and Space Physics 17(June): $626 \mathrm{ff}$. 